\title{
INVESTIGATING ZAKAT PAYMENT OF THAI MUSLIMS ${ }^{1}$
}

\author{
Sawarai Boonyamanond ${ }^{1}$ and Papusson Chaiwat ${ }^{2}$ \\ ${ }^{1}$ Chulalongkorn University, Thailand, sawarai.b@chula.ac.th \\ ${ }^{2}$ Chulalongkorn University, Thailand, papusson.cha@gmail.com
}

\begin{abstract}
This study examines the payment of zakat among Thai Muslims whose wealth exceeds the minimum threshold (nisab) and who are thus obliged to pay zakat. It attempts to assess whether the amount of zakat paid fulfils the requirement and to determine the amount of zakat overpaid or underpaid, based on $2.5 \%$ of zakatable wealth, as measured by income from different sources. Using 460 questionnaires collected from Thai Muslims aged 15 years and over who paid zakat in 2015, this study employs a two-part model. The first part analyses the probability of fulfilling or not fulfilling an obligation to fully pay zakat using the Multinomial Logit method of estimation, while the second part focuses on the amount of zakat overpaid/underpaid using the Ordinary Least Squares method. It is found that the probability of paying the required zakat will increase and the amount of zakat underpaid will decrease if a person pays zakat more than once a year, or the value of a person's net assets increases. In addition, for those whose zakat payments already exceed the amount required, the trust and accountability of the intermediate institutions or individuals who manage zakat will positively affect the amount of zakat overpaid considerably. Therefore, official organisations responsible for the collection and distribution of zakat at the community, provincial, regional and national levels should be established with integrity, transparency and good governance so that people are encouraged to pay more zakat and the lives of those in need can be lifted accordingly.
\end{abstract}

Keywords: Zakat payment, Compulsory charity, Thai muslims.

JEL Classification: D91; Z12; C31.

Article history:

Received : October 28, 2018

Revised : : December 8, 2019

Accepted : January 8, 2020

Available online : February 28, 2020

https://doi.org/10.21098/jimf.v6i1.1201

1 This paper is part of a research project on the Zakat Payment of Thai Muslims, funded by the Thailand Research Funds, Thailand. 


\section{I.INTRODUCTION}

\subsection{Background}

Zakat is a religious concept that aims to purify one's mind and eliminate the stinginess of the mind. The payment of zakat is one of the significant principles to which Muslims adhere with the goal of "... promoting equality, kindness, generosity, helpfulness; eradicating devils that are likely to destroy peacefulness and security, including everything that is against this world's and next world's peace" (Hasalem et al., 2007), as well as contributing to others in the same society. Academically, 'Zakat' refers to a certain proportion of wealth, the owners of which, as followers of Islam, are obliged to pay to people who are eligible to receive it in accordance with the criteria and conditions specified by Islam (Al Qaradawi, 1981 as cited in Numsuk et al., 2012). Therefore, the payment of zakat is carried out based on the same mechanism as personal income taxation; as such, it has a role in alleviating problems with the distribution of income or wealth in unequal economic systems.

Zakat is also considered as an index of national economic growth (Sarea, 2012) since it reflects the economic surplus that people transfer to those with lower economic statuses, thereby increasing the purchasing power of those individuals to obtain goods and services and subsequently boosting the economy (Abu Bakar \& Abdul Rahman, 2007; Ahmad, 1977 ). This is consistent with data reported by Thomson Reuters (2014) who estimated the zakat potential of Muslim nations offered during the period 2008-2011 in the form of Malikite views ${ }^{2}$. They found that Pakistan had the highest proportion of zakat as a share of gross domestic product, at $4.18 \%$, followed by Bangladesh at 3.92\%, Indonesia at 3.82\%, Malaysia at $2.66 \%$, Brunei at $2.25 \%$, Singapore at $0.65 \%$ and India at $0.63 \%$. It is thus clear to see that zakat plays a fundamental role in improving the living conditions of Muslims in such countries.

According to the 2010 Population and Housing Census, there are about 3.3 million Thai Muslims, although they account for only $4.94 \%$ of the total population of Thailand. Of this total, around $77.92 \%$ reside in the southern part of Thailand (National Statistical Office of Thailand, 2010). There is a very limited number of studies on the zakat payment behaviour of Thai Muslims due to the fact that Thailand has never officially collected data on its national zakat payments. Nevertheless, studies have been conducted on the pronounced effects of zakat on addressing poverty reduction among Thai Muslims. Suwanhirunkul (2013) investigated the effectiveness of distributing zakat to poor Thai Muslims throughout the country and discovered it was able to reduce the proportion of poor Muslims by $24 \%$ nationally. This finding is in line with Suwanhirunkul (2014), who reported that in 2009, zakat contributed to increasing education spending among Thai Muslim families who received it.

\footnotetext{
2 The basis for zakat includes buildings and other fixed assets, with the exception of those assigned for personal and family use.
} 


\subsection{Objective}

Despite the fact that zakat is a form of compulsory charity that every Muslim is obliged to pay, in addition to the benefits that have been commonly realised as a result in both spiritual and economic dimensions, in practice it is still possible to find Thai Muslims who refrain from paying zakat on his/her wealth (Hasalem et al., 2007). This study thus aims to examine how zakat is paid, whether or not zakat payers have fulfilled their religious obligation, how much they overpay/underpay zakat, and how demographic, socioeconomic, religious and institutional factors affect the amount of zakat paid. An analysis of the zakat payment behaviour of Thai Muslims will provide insightful information that can help tackle problems of underpaid zakat and can serve as a mechanism for eradicating poverty in Muslim society in the future, which to the best of our knowledge has not been found in the literature.

\section{LITERATURE REVIEW}

A body of research exists on the factors affecting the zakat payment behaviour of Muslims. Amin (2003) and Kamil (2005) indicate that demographic factors including gender, age, status, the level of education and the number of dependents influence the zakat payment behaviour of Muslims in all countries with Muslim populations. Meanwhile, a number of religious factors, namely worship (Firdaus et al., 2012; Reinstein, 2006), purification (Muda et al., 2006), individual understanding of Islamic principles (Aldit, 1998 as cited in Firdaus et al., 2012; Al Qaradawi, 1999) and faith (Lunn et al., 2001; Reinstein, 2006) are also factors that significantly affect the zakat payment behaviour of Muslims.

Johari (2004) explores the importance of institutional roles in zakat payment behaviour in order to foster social equality and financially strengthen the sectors that require assistance, noting that institutions should be trustworthy, fair and ethical according to the religious principles of management, and that zakat must be managed in a transparent and clear manner. The timing of paying zakat is another influencing factor that also affects the image of organisations (Khaf, 1995; Mujaini, 1995; Nik Mustapha, 1991; Wahid \& Kadar, 2010). In addition, organisations should seek to develop more creative ideas and innovations to encourage the payment of zakat (Abdul Rahim, 2006; Al-Quardhawi, 1999; Mujaini, 2005).

Since the act of making zakat payments resembles that of making donations, there are significant factors that influence it. These include direct and indirect payments (Sura et al., 2017 ), socioeconomic status (Baruch \& Sang, 2012; Kari, 2013; Lee \& Chang, 2007), housing (Treiblmaier \& Pollach, 2006) and individual perception, values, understanding and attitudes to giving zakat (Johnson \& Grimm, 2010; Kari, 2013). It is also found that factors related to feelings, which include personal instincts and extrinsic motivation, influence the payment of zakat. The personal instincts that come into play in zakat payment consist of the sense of responsibility (Kari, 2013; Lee \& Chang, 2007), the demand for change (Kari, 2013; Pentecost \& Andrew, 2010) and emotional bonds (Knowles et al., 2012). Extrinsic motivation covers the reliability of zakat recipients (Cherry, 2013; Johnson \& Grimm, 2010; Treiblmaier \& Pollach, 2006). 
Aside from the above-mentioned factors, charitable organisations impact people's decision to pay donations (Bereczkei et al., 2007). Those who see how others benefit and decide to donate to charity must believe in social interdependence, public benefit and the welfare of others (Batson et al., 2003; Milinski et al., 2002; Oswald, 2002; Preston \& deWaal, 2002; Roberts, 1998).

In contrast, the paying of taxes equates to adherence to regulations and other related laws and thus involves tax audits (Slemrod et al., 2001), an understanding of the importance of taxes (Cummings et al., 2006; Torgler, 2002), social values (Bobek et al., 2007; Wenzel, 2004), justice, and concern about tax payments (Kirchler et al., 2008), as well as taxpayers' knowledge about the relevant laws (McKerchar, 1995). Various factors therefore have a significant effect on compliance with laws and regulations on tax payment.

\section{METHODOLOGY}

This study adopts a two-part model to analyse factors determining the probability of fulfilling or not fulfilling an obligation to fully pay zakat by considering the amount of zakat that Thai Muslims actually paid in 2015, compared to the amount that Muslims are expected to pay according to the Islamic principle, stating that anyone whose wealth exceeds the nisab, which is the minimum amount of wealth ${ }^{3}$ (Alfitri, 2005), must pay zakat at the rate of $2.5 \%$ of their total wealth. In this study, wealth accumulated from one's main source of income (wages, salaries and/ or profits), plus other sources of income (overtime payments, bonus payments, tips, child benefit, pension and so on) are considered. To analyse zakat payment behaviour, 460 Muslims who reside in the central, northern and southern regions were purposively sampled as the study is focused only on the payment behaviour of those who actually paid zakat in 2015. The respondents are divided into three groups:

1) Group 1: People who made the full zakat payment. This refers to those with income above the nisab and who pay an amount of zakat equal to or more than $2.5 \%$ of their income.

2) Group 2: People who do not make the full zakat payment. This refers to those with income above the nisab but who pay zakat amounting to less than $2.5 \%$ of their income.

3) Group 3: People who do not have to pay zakat. This refers to those whose income does not meet the nisab but who still pay zakat.

The models contain a number of variables based on the existing literature as well as suggestions from Islamic studies scholars in Thailand. The multinomial logistic regression method is used to capture the probability that people will pay zakat. The equations for the two-part model are adjusted as follows for use in examining the zakat payment behaviour of Thai Muslims:

$$
\ln \left[\frac{P(\text { Group }=2)}{P(\text { Group }=1)}\right]=
$$

\footnotetext{
3 Nisab, or the minimum threshold of zakat payment, in this study, amounts to 108,665 baht, calculated based on 85 grams of gold, or 5.5760 baht, multiplied by the average price of gold in 2015, at 19,488.17 baht per 15.244 grams of gold (1 Thai gold bar baht).
} 
f(Gender, Age, Region, Relationship, Family member, Formal education, In(Income), In(Net assets), Work status, Madhhab, Frequency, Understanding score, Prayer, Fasting, Faith, Necessity, Benefit, Channel, Trust)

$\ln \left[\frac{P(\text { Group }=3)}{P(\text { Group }=1)}\right]=$

f(Gender, Age, Region, Relationship, Family member , Formal education, In(Income), In(Net assets), Work status, Madhhab, Frequency, Understanding score, Prayer, Fasting, Faith, Necessity, Benefit, Channel, Trust)

$\ln \left[\left|\operatorname{Zakat}_{i}(\operatorname{group}=n)-Z_{i}\right|\right]=$

f(Gender, Age, Region, Marital Status, Relationship, Family member, Formal education, In(Income), In(Net assets), Work status, Religious education, Madhhab, Frequency, Understanding score, Prayer, Fasting, Faith, Necessity, Benefit, Channel, Trust)

where $n$ represents each zakat payment group that an individual is categorised into and $i$ represents each individual who paid zakat. Table 1 contains all the variables included in the model.

Table 1.

Variable description

\begin{tabular}{|c|c|c|c|}
\hline Definition & $\begin{array}{c}\text { Variable } \\
\text { name }\end{array}$ & Unit & Range \\
\hline \multicolumn{4}{|l|}{ Dependent variables } \\
\hline Zakat payment behaviour & Group & Level & $\begin{array}{l}=1 \text { People who made the full zakat } \\
\text { payment } \\
=2 \text { People who did not make the full } \\
\text { zakat payment } \\
=3 \text { People who do not have to pay zakat }\end{array}$ \\
\hline $\begin{array}{l}\text { The total amount of zakat } \\
\text { paid in the zakat year }\end{array}$ & Zakat & Baht & Equal to or greater than 1 \\
\hline The amount of nisab & $\mathrm{Z}$ & Baht & Equal to or greater than 1 \\
\hline \multicolumn{4}{|l|}{ Independent variables } \\
\hline \multicolumn{4}{|l|}{ Demographic factors } \\
\hline Gender & Male & 0 or 1 & $=1$ Male \\
\hline (Reference group: Female) & & & $=0$ Female \\
\hline Age & Age & Year & Equal to or greater than 15 \\
\hline \multirow[t]{2}{*}{$\begin{array}{l}\text { Region } \\
\text { (Reference group: Central) }\end{array}$} & North & 0 or 1 & $\begin{array}{l}=1 \text { North } \\
=0 \text { Others }\end{array}$ \\
\hline & South & 0 or 1 & $\begin{array}{l}=1 \text { South } \\
=0 \text { Others }\end{array}$ \\
\hline \multirow[t]{2}{*}{$\begin{array}{l}\text { Marital status } \\
\text { (Reference group: Single) }\end{array}$} & Married & 0 or 1 & $\begin{array}{l}=1 \text { Married } \\
=0 \text { Others }\end{array}$ \\
\hline & Divorced & 0 or 1 & $\begin{array}{l}=1 \text { Divorced } / \text { Widowed } / \text { Separated } \\
=0 \text { Others }\end{array}$ \\
\hline
\end{tabular}


Table 1.

Variable description (Continued)

\begin{tabular}{|c|c|c|c|}
\hline Definition & $\begin{array}{c}\text { Variable } \\
\text { name }\end{array}$ & Unit & Range \\
\hline \multirow{5}{*}{$\begin{array}{l}\text { Relationship to head of } \\
\text { household } \\
\text { (Reference group: } \\
\text { Non-relative) }\end{array}$} & Head & 0 or 1 & $\begin{array}{l}=1 \text { Head } \\
=0 \text { Others }\end{array}$ \\
\hline & Spouse & 0 or 1 & $\begin{array}{l}=1 \text { Spouse } \\
=0 \text { Others }\end{array}$ \\
\hline & Child & 0 or 1 & $\begin{array}{l}=1 \text { Child } / \text { Grandchild } \\
=0 \text { Others }\end{array}$ \\
\hline & Parent & 0 or 1 & $\begin{array}{l}=1 \text { Parent } \\
=0 \text { Others }\end{array}$ \\
\hline & Sibling & 0 or 1 & $\begin{array}{l}=1 \text { Sibling } / \text { Other relative } \\
=0 \text { Others }\end{array}$ \\
\hline Number of family members & $\begin{array}{l}\text { Family } \\
\text { Members }\end{array}$ & Person & Equal to or greater than 1 \\
\hline \multicolumn{4}{|l|}{ Socioeconomic factors } \\
\hline Years of formal education & $\begin{array}{c}\text { Formal } \\
\text { education }\end{array}$ & Year & Equal to or greater than 1 \\
\hline $\begin{array}{l}\text { The amount of income } \\
\text { earned }\end{array}$ & Income & Baht & Equal to or greater than 0 \\
\hline $\begin{array}{l}\text { The amount of net assets } \\
\text { acquired }\end{array}$ & Net assets & Baht & Less than, equal to or greater than 0 \\
\hline \multirow{8}{*}{$\begin{array}{l}\text { Work status } \\
\text { (Reference group: } \\
\text { Economically inactive) }\end{array}$} & Employer & 0 or 1 & $\begin{array}{l}=1 \text { Employer } \\
=0 \text { Others }\end{array}$ \\
\hline & Own account & 0 or 1 & $\begin{array}{l}=1 \text { Own-account worker } \\
=0 \text { Others }\end{array}$ \\
\hline & $\begin{array}{l}\text { Unpaid worker } \\
\text { Gov employee }\end{array}$ & 0 or 1 & $\begin{array}{l}=1 \text { Unpaid family worker } \\
=0 \text { Others }\end{array}$ \\
\hline & & 0 or 1 & $\begin{array}{l}=1 \text { Government employee } \\
=0 \text { Others }\end{array}$ \\
\hline & & 0 or 1 & $=1$ State enterprise employee \\
\hline & State employee & 0 or 1 & $\begin{array}{l}=0 \text { Others } \\
=1 \text { Private sector employee }\end{array}$ \\
\hline & $\begin{array}{c}\text { Private } \\
\text { employee }\end{array}$ & 0 or 1 & $\begin{array}{l}=0 \text { Others } \\
=1 \text { Imam } / \text { Islamic teacher } \\
=0 \text { Others }\end{array}$ \\
\hline & Imam & & \\
\hline \multicolumn{4}{|l|}{ Religious factors } \\
\hline \multirow{4}{*}{$\begin{array}{l}\text { Religious education } \\
\text { (Reference group: } \\
\text { Never studied) }\end{array}$} & Elementary & 0 or 1 & $\begin{array}{l}=1 \text { Elementary Islamic studies } \\
=0 \text { Others }\end{array}$ \\
\hline & Intermediate & 0 or 1 & $\begin{array}{l}=1 \text { Intermediate Islamic studies } \\
=0 \text { Others }\end{array}$ \\
\hline & Advanced & 0 or 1 & $\begin{array}{l}=1 \text { Advanced Islamic studies or higher } \\
=0 \text { Others }\end{array}$ \\
\hline & Informal & 0 or 1 & $\begin{array}{l}=1 \text { Informal Islamic studies } \\
=0 \text { Others }\end{array}$ \\
\hline
\end{tabular}


Table 1.

Variable description (Continued)

\begin{tabular}{|c|c|c|c|}
\hline Definition & $\begin{array}{c}\text { Variable } \\
\text { name }\end{array}$ & Unit & Range \\
\hline \multirow{4}{*}{$\begin{array}{l}\text { School of thought } \\
\text { (Madhhab) adhered to } \\
\text { (Reference group: Hanafi) }\end{array}$} & Shafi'i & 0 or 1 & $\begin{array}{l}=1 \text { Shafi'i } \\
=0 \text { Others }\end{array}$ \\
\hline & Hanbali & 0 or 1 & $\begin{array}{l}=1 \text { Hanbali } \\
=0 \text { Others }\end{array}$ \\
\hline & Sunni & 0 or 1 & $\begin{array}{l}=1 \text { Sunni } \\
=0 \text { Others }\end{array}$ \\
\hline & Not specific & 0 or 1 & $\begin{array}{l}=1 \text { Not specific } \\
=0 \text { Others }\end{array}$ \\
\hline \multirow[t]{2}{*}{$\begin{array}{l}\text { Frequency of zakat payment } \\
\text { (Reference group: Once) }\end{array}$} & Twice & 0 or 1 & $\begin{array}{l}=1 \text { Twice } \\
=0 \text { Others }\end{array}$ \\
\hline & Thrice & 0 or 1 & $\begin{array}{l}=1 \text { Thrice or more } \\
=0 \text { Others }\end{array}$ \\
\hline $\begin{array}{l}\text { Total score in zakat } \\
\text { payment understanding }\end{array}$ & Score & Score & $0-24$ \\
\hline $\begin{array}{l}\text { Performing daily prayer } \\
\text { (Reference group: Not } \\
\text { completed) }\end{array}$ & Prayer & 0 or 1 & $\begin{array}{l}=1 \text { Completed prayer } \\
=0 \text { Not completed }\end{array}$ \\
\hline $\begin{array}{l}\text { Fulfilling annual fasting in } \\
\text { Ramadan (Reference group: } \\
\text { Not completed) }\end{array}$ & Fasting & 0 or 1 & $=1$ Completed fasting \\
\hline Interest in Islamic principles & Faith & Level & $\begin{array}{l}=0 \text { Not completed } \\
=5 \text { Extremely agree } \\
=4 \text { Very agree } \\
=3 \text { Somewhat agree } \\
=2 \text { Somewhat disagree } \\
=1 \text { Very disagree } \\
=0 \text { Extremely disagree }\end{array}$ \\
\hline $\begin{array}{l}\text { Perception of the necessity } \\
\text { of paying zakat }\end{array}$ & Necessity & Level & $\begin{array}{l}=5 \text { Extremely agree } \\
=4 \text { Very agree } \\
=3 \text { Somewhat agree } \\
=2 \text { Somewhat disagree } \\
=1 \text { Very disagree } \\
=0 \text { Extremely disagree }\end{array}$ \\
\hline $\begin{array}{l}\text { Perception of the positive } \\
\text { effects of zakat payment on } \\
\text { social welfare }\end{array}$ & Welfare & Level & $\begin{array}{l}=5 \text { Extremely agree } \\
=4 \text { Very agree } \\
=3 \text { Somewhat agree } \\
=2 \text { Somewhat disagree } \\
=1 \text { Very disagree } \\
=0 \text { Extremely disagree }\end{array}$ \\
\hline $\begin{array}{l}\text { Channel of zakat payment } \\
\text { (Reference group: Direct) }\end{array}$ & Indirect & 0 or 1 & $\begin{array}{l}=1 \text { Indirect } \\
=0 \text { Direct }\end{array}$ \\
\hline $\begin{array}{l}\text { Trust in people/ } \\
\text { organisations who } \\
\text { distribute zakat }\end{array}$ & Trust & Level & $\begin{array}{l}=5 \text { Extremely agree } \\
=4 \text { Very agree } \\
=3 \text { Somewhat agree } \\
=2 \text { Somewhat disagree } \\
=1 \text { Very disagree } \\
=0 \text { Extremely disagree }\end{array}$ \\
\hline
\end{tabular}


The Cronbach's alpha test for scaled questions produced a result of 0.8359 , which is higher than the critical point of 0.8 , therefore signifying the reliability and internal consistency of the questionnaire.

\section{RESULTS AND ANALYSIS}

\subsection{General Characteristics of the Sample}

The sample consists of 460 respondents, more than $63 \%$ of whom are male and live in the central, northern and southern parts of Thailand. More than two-fifths of the respondents are of late working age, ranging from 45 to 59 years old, resulting in a relatively high average age of the sample of 49.19 years. Approximately threefourths of those in the sample group are married and more than half are the head of the family, with the average number of family members being 4.97.

Table 2.

Descriptive statistics

\begin{tabular}{lcc}
\hline Characteristics & $\begin{array}{c}\text { Number } \\
(\mathbf{n}=\mathbf{4 6 0})\end{array}$ & Percentage \\
\hline Gender & & \\
Male & 291 & 63.26 \\
Female & 169 & 36.74 \\
\hline Age & & \\
$15-29$ & 28 & 6.09 \\
$30-44$ & 128 & 27.83 \\
$45-59$ & 189 & 41.09 \\
60-74 & 92 & 20.00 \\
75 and over & 9 & 1.96 \\
N/A & 14 & 3.04 \\
\hline Region & & \\
Central & 158 & 34.35 \\
North & 163 & 35.43 \\
South & 139 & 30.22 \\
\hline Marital status & & \\
Single & 75 & 16.30 \\
Married & 348 & 75.65 \\
Widowed/Divorced/Separated & 28 & 6.09 \\
N/A & 9 & 1.96 \\
\hline Relationship to head of household & & \\
Head & 250 & 54.35 \\
Spouse & 115 & 25.00 \\
Child & 62 & 13.48 \\
Parent/Parent-in-law/Grandparent & 8 & 1.74 \\
Grandchild & 1 & 0.22 \\
Sibling/Other relative & 9 & 1.96 \\
Non-relative & 5 & 1.09 \\
N/A & 10 & 2.17 \\
\hline
\end{tabular}


Table 2.

Descriptive statistics (Continued)

\begin{tabular}{|c|c|c|}
\hline Characteristics & $\begin{array}{l}\text { Number } \\
(\mathrm{n}=460)\end{array}$ & Percentage \\
\hline \multicolumn{3}{|l|}{ Number of family members } \\
\hline 01-Feb & 42 & 9.13 \\
\hline 03-Apr & 151 & 32.83 \\
\hline 05-Jun & 179 & 38.91 \\
\hline 07-Sep & 62 & 13.48 \\
\hline 10 and more & 16 & 3.48 \\
\hline N/A & 10 & 2.17 \\
\hline \multicolumn{3}{|l|}{ Formal educational level } \\
\hline Never studied & 4 & 0.87 \\
\hline Primary & 45 & 9.78 \\
\hline Lower secondary & 51 & 11.09 \\
\hline Upper secondary & 69 & 15.00 \\
\hline Diploma/Vocational & 55 & 11.96 \\
\hline Bachelor's or higher & 234 & 50.87 \\
\hline N/A & 2 & 0.43 \\
\hline \multicolumn{3}{|l|}{ Work status } \\
\hline Employer & 76 & 16.52 \\
\hline Own-account worker & 138 & 30.00 \\
\hline Unpaid family member & 18 & 3.91 \\
\hline Government employee & 79 & 17.17 \\
\hline State enterprise employee & 23 & 5.00 \\
\hline Private sector employee & 59 & 12.83 \\
\hline Imam/Islamic teacher & 8 & 1.74 \\
\hline Economically inactive & 40 & 8.70 \\
\hline N/A & 19 & 4.13 \\
\hline \multicolumn{3}{|l|}{ Religious educational level } \\
\hline Never studied & 56 & 12.17 \\
\hline Elementary & 230 & 50.00 \\
\hline Intermediate & 48 & 10.43 \\
\hline Advanced & 73 & 15.87 \\
\hline Informal & 25 & 5.43 \\
\hline N/A & 28 & 6.09 \\
\hline \multicolumn{3}{|l|}{ School of thought (Madhhab) } \\
\hline Hanafi & 177 & 38.48 \\
\hline Shafi'i & 242 & 52.61 \\
\hline Hanbali & 2 & 0.43 \\
\hline Sunni & 32 & 6.96 \\
\hline Not specific & 2 & 0.43 \\
\hline N/A & 5 & 1.09 \\
\hline
\end{tabular}

It is found that the respondents have fairly high levels of education. This can be seen in the fact that $51 \%$ of the total graduated with a Bachelor's degree or higher. Almost 35\% are employees of the government, private companies or state enterprises. Most of the respondents do not earn very high incomes, ranging from 100,001 to 300,000 baht per year. Nevertheless, the average total income is quite high, at 465,819.10 baht per year, with a standard deviation of 870,721.10 baht, suggesting a relatively large disparity in the respondents' incomes. Approximately 
one out of three of the sample have net assets of no more than 100,000 baht, with an average of 375,230.20 baht and a standard deviation of 3,596,505 baht.

The vast majority of the respondents have religious knowledge to a certain extent. This is evidenced by the fact that half of them completed elementary Islamic studies. One interesting point is that the respondents adhere to the principles of differing schools of thought (Madhhabs), depending on the region in which they live. Specifically, most of the respondents living in the central and southern parts of Thailand observe the principles of the Shafi'i school of thought, while the great majority of those who reside in the northern part follow the principles of the Hanafi school of thought.

With respect to the zakat payment behaviour of the respondents in the sample group, it is found that the amounts of zakat given to other people or organisations ranged from 75 to 1,000,000 baht, with an average of 30,700.82 baht. Nearly $38 \%$ of the sample paid zakat in the zakat year of 2015 at a rate of no more than 5,000 baht, and approximately $18 \%$ paid amounts of zakat ranging from 5,001 to 10,000 baht. Most of the respondents generally paid zakat once a year in the zakat year of 2015, particularly in the holy month of Ramadan. The direct zakat payments target eight types of recipients, with the highest proportion going to the poor and the needy.

In regard to the types of assets and debts which should or should not be used to calculate net assets, overall, the respondents have a correct understanding of the criteria for assessing the amounts of net assets or debts to use in calculating the amounts of zakat to be paid. Of the total respondents, $51 \%$ have a score of less than or equal to 12 out of 24 in such understanding, whereas the other $49 \%$ have scores above or equivalent to 13 .

\subsection{Two-Part Model Results}

The results of analysing the effects of demographic, socioeconomic, religious and institutional factors on the probability of a change in zakat payment behaviour and differences in the specified amounts of zakat paid are displayed in Table 3. Column 1 shows the coefficients of the determining factors that were obtained from the multinomial logistic regressions to capture the probability of people who do not fully pay zakat (Group 2), compared with those who do fully pay zakat (Group 1), in logarithmic form. Column 2 presents the coefficients of the determining factors comparing the probability of people who do not have to pay zakat but who still made payment (Group 3) with those who did fully pay zakat (Group 1). Columns 3-5 show the value of marginal effects of the determining factors for the group who fully pay zakat, those who do not fully pay zakat and those who do not have to pay zakat, respectively. Columns 6-8 contain the results of the ordinary least squares method of estimation, which as the independent variable used the discrepancy in the amounts of zakat that the respondents overpaid or underpaid based on $2.5 \%$ of personal income. 


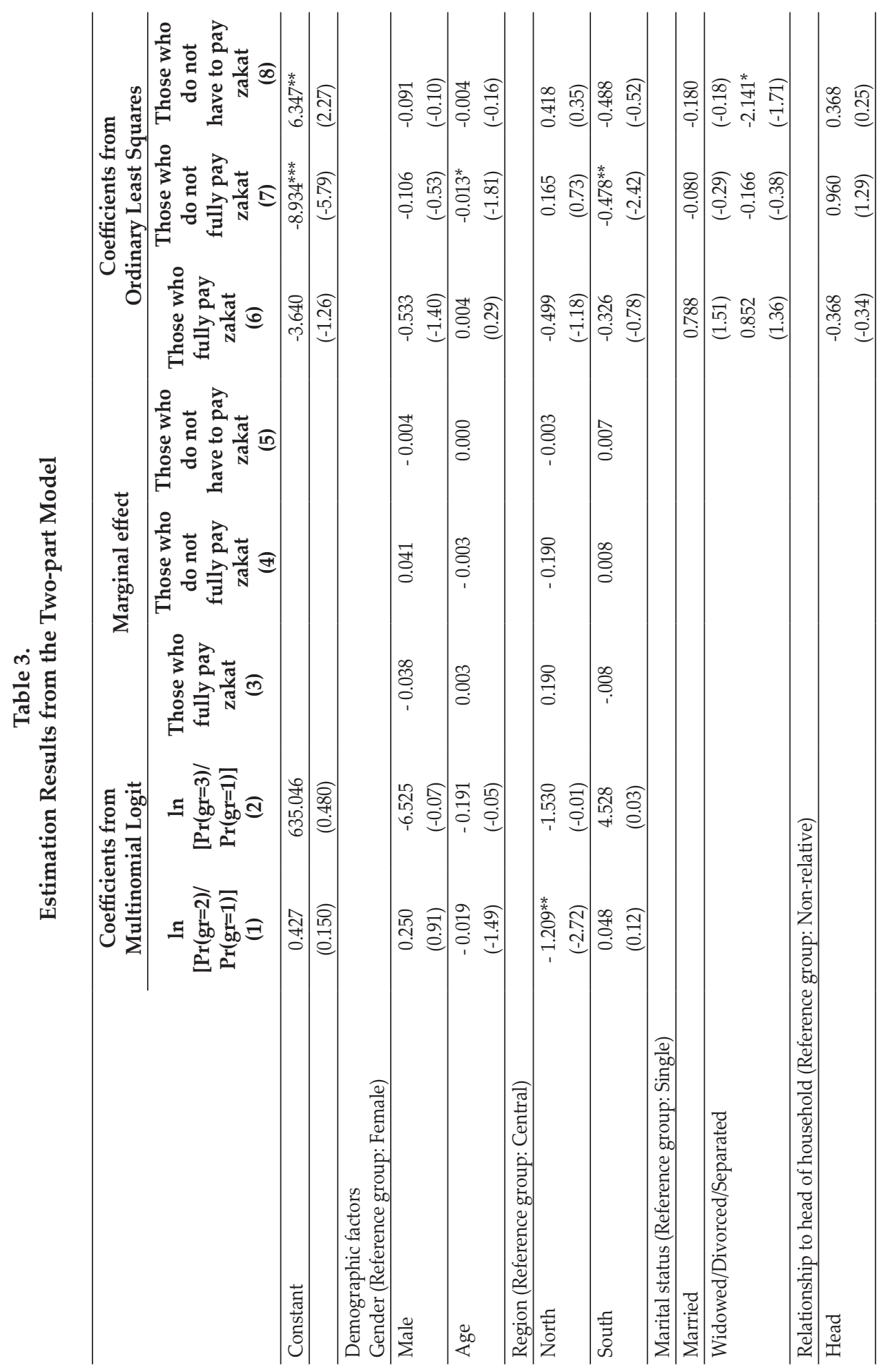




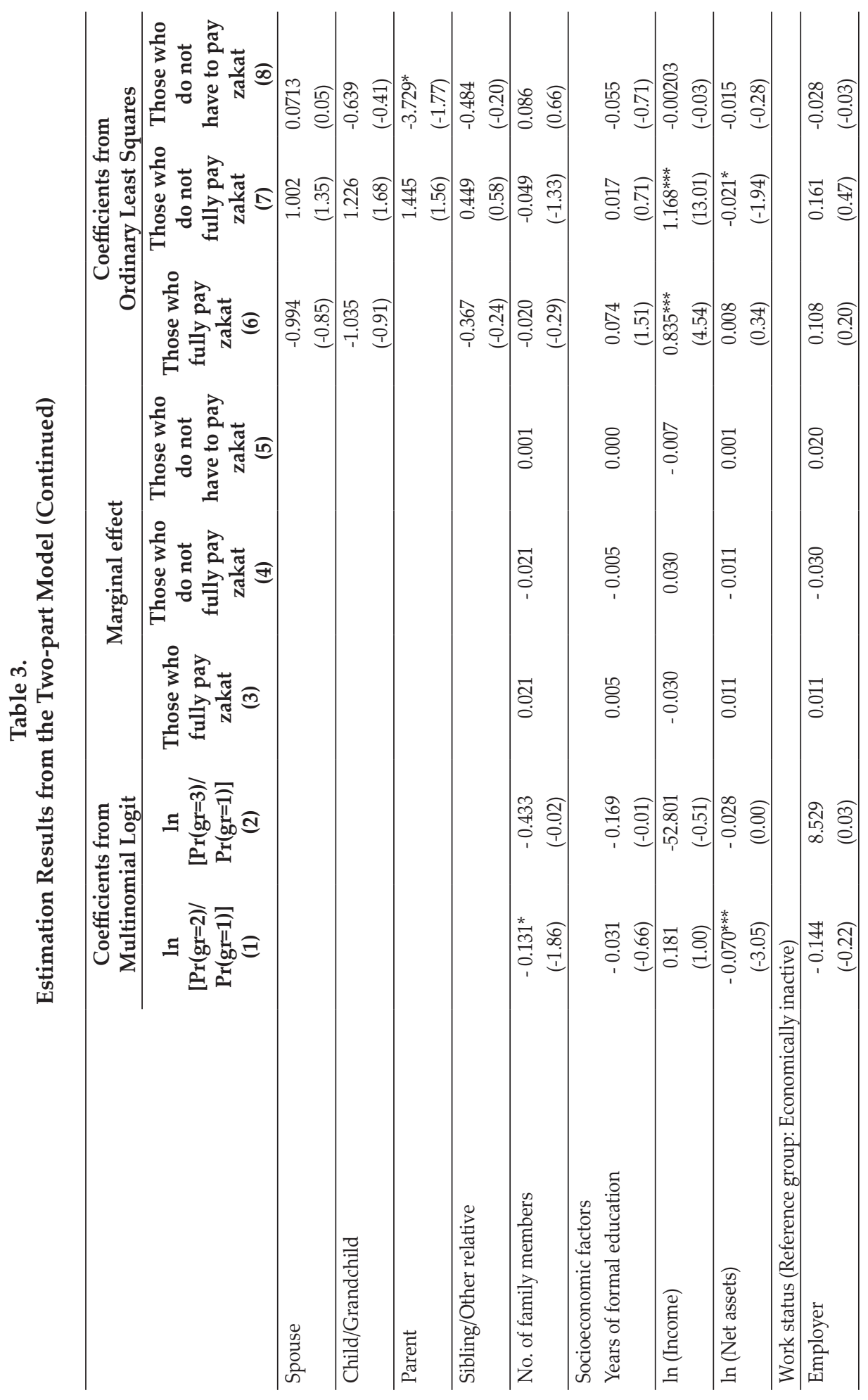




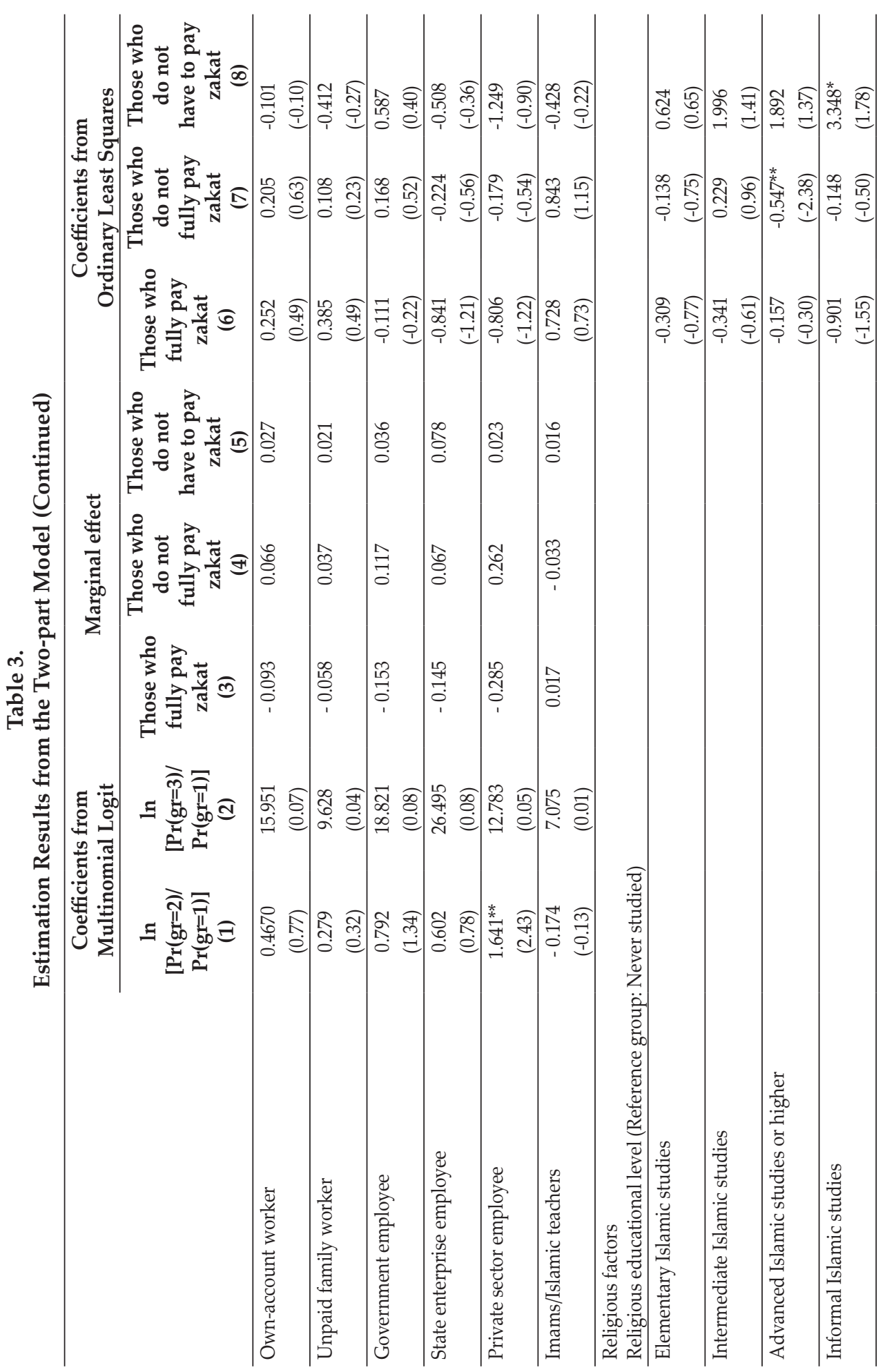




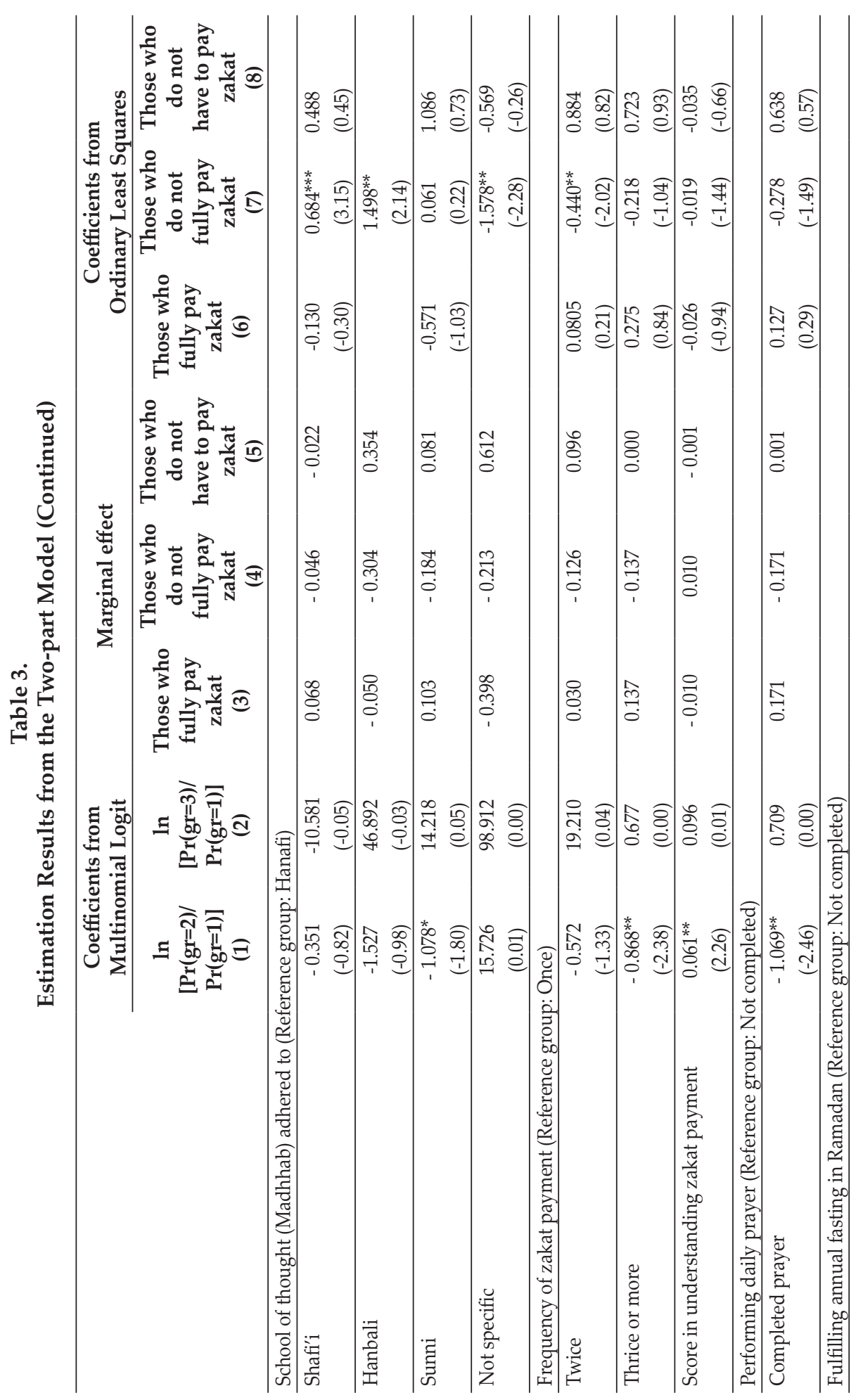




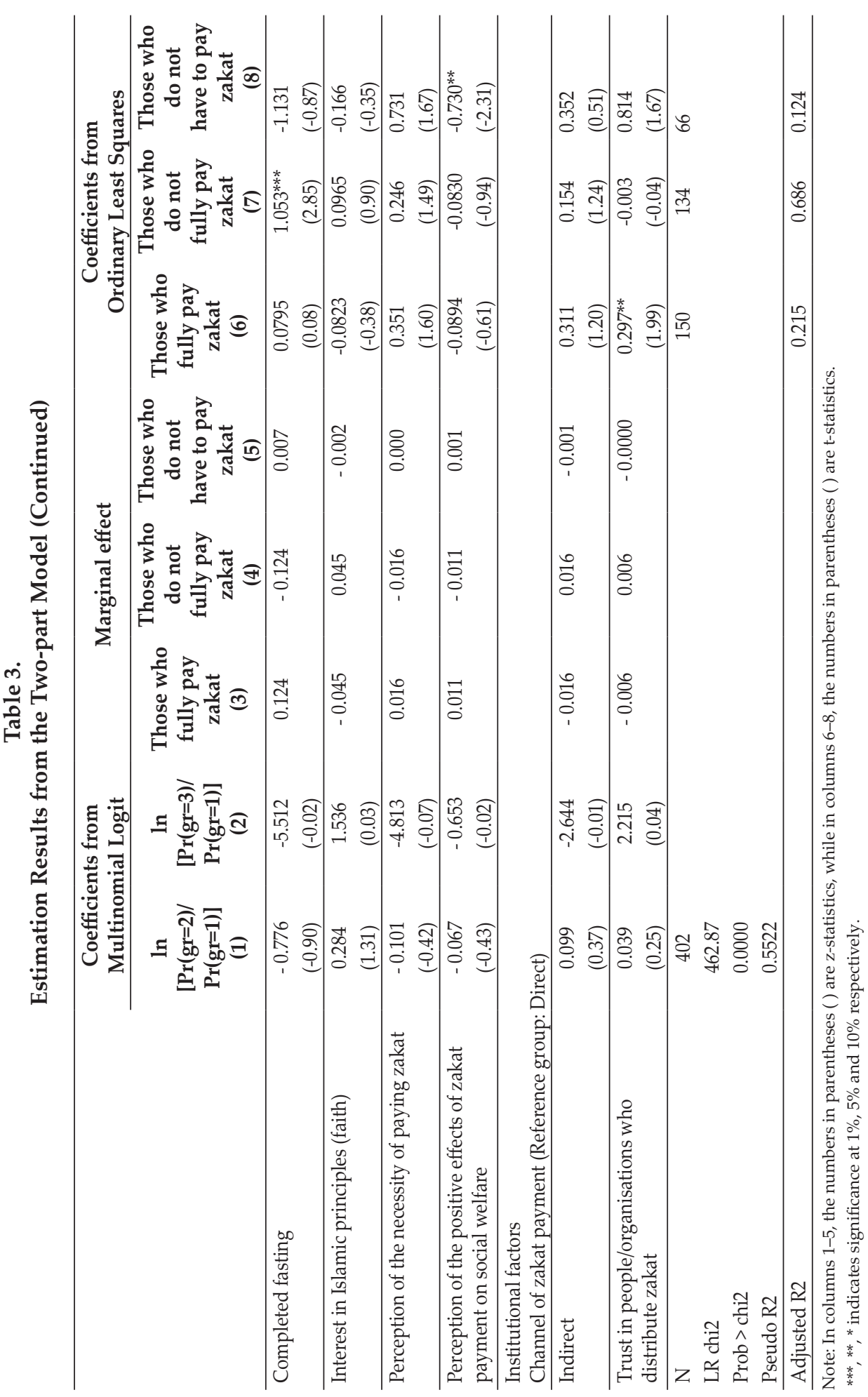


The findings show that the determining factors have significant effects on zakat payment behaviour. The key demographic factors are age and household size. The respondents' zakat payment behaviours tend to change in a positive way, provided that the participants in the sample are older or live in a large family. These groups have incremental stability in terms of family, work and financial status, which means they might pay zakat on behalf of their other household members who cannot pay fully based on the zakat payment criteria. To be more precise, an additional family member would raise the probability of complete zakat payment by $0.021 \%$ on average and reduce the probability of incomplete zakat payment by $0.021 \%$. Likewise, for those respondents who fail to fulfil their required zakat payment, the amount of zakat underpaid is likely to fall by $1.3 \%$ as they grow older.

Additionally, there is a correlation between region and zakat payment behaviour. To illustrate, the respondents who live in the northern part of Thailand tend to pay zakat more fully than those who reside in the central part. However, for those in the northern part who do not fulfil their obligated zakat payment, the amount of unpaid zakat exceeds that of those living in the central part. In contrast, the probability of incomplete zakat payment for those living in the southern part is found to be indifferent from those dwelling in the central part - Yet, the amount of zakat underpaid is significantly lower than the amount underpaid by the respondents living in the central part. This may be attributed to the different environment of the Thai Muslim community in each region. Unlike Thai Muslims in the deep south of the country, those who reside in the north are minorities in non-Muslim society. They are closely tied to one another in small and confined Muslim communities and thus tend to follow their religious practices profoundly. Together with numerous efforts to support zakat fund establishment at the provincial and regional levels, those living in this area are likely to have the highest probability of fully paying zakat.

Other than the demographic factors, the amount of income respondents earn and the value of the net assets they accumulate are socioeconomic factors that influence zakat payment behaviour in the opposition direction. For those who do not fully pay zakat, a $1 \%$ increase in income does not lead to desirable payment behaviours, but instead deviates further from good practices by increasing the amount of underpaid zakat in the zakat year by $1.168 \%$. On the contrary, a $1 \%$ increase in net assets would significantly raise the probability of complete zakat payment by $0.011 \%$ on average; in other words, it would lower the probability of incomplete zakat payment by the same amount, and reduce the amount of underpaid zakat by $0.021 \%$.

When individuals acquire new assets, particularly tangible stores of value like investment properties, gold and jewellery, such changes tend to have a more prominent effect on their zakatable wealth and the amount of zakat they are required to pay, for the reason that these things are generally of high value and thus can be easily realised by the owners and noticed by others. This sits in contrast to any increases in liquid assets, namely income, which might lead to rises in both consumption and non-consumption expenditure, thereby resulting in a lower amount of zakatable wealth and the corresponding amount of zakat paid. This is consistent with the finding that being an employee of a company or private 
organisation who receives a fixed income is a socioeconomic factor that negatively influences zakat payment behaviour.

As for religious factors, people who pay zakat more than once a year tend to fully pay it more than those who pay zakat only once a year. The respondents who pay zakat more than twice a year have a higher probability of completing zakat payment and a lower probability of failing to make zakat payment by $0.137 \%$. Moreover, for those who cannot fulfil the required zakat, paying zakat twice a year would significantly reduce the amount of underpaid zakat. This is because a once-a-year zakat payment during the zakat year requires information on any changes in total wealth that have occurred throughout the year and which contain a number of details. In this case, if an individual inaccurately estimates his/her wealth, then the calculated amounts of zakat to be paid will be erroneous. Furthermore, assuming that one has to pay the full zakat amount in the zakat year, he/she may be hesitant to pay it in full as they may consider it to be too high.

For other religious activities such as daily prayer and annual fasting during the month of Ramadan, the respondents' interest in the in-depth study of Islam, as well as their perceptions of the necessity of zakat payment and benefits of zakat for social welfare, which to some extent can reflect their religious faith, no clear, strong statistical significance is found, which contradicts the hypothesis previously formulated.

Interestingly, with regard to the scores on understanding the zakat payment criteria, it is found that the better the sample group understands the criteria for calculating zakat, the less likely it is there will be a fully completed zakat payment. It is possible that those who understand the means of calculating the amount of net assets which are used to assess the amount of zakat to be paid, according to Islamic prescriptions, are more inclined to refrain from paying zakat, irrespective of a matter of conscience or the necessity of zakat payment, as in cases of tax evasion. However, when the respondents attain religious education at the higher levels, the amount of zakat not being fully paid, or where the amount paid is less than the specified amount, will decrease.

Although the principles of the schools of thought (Madhhabs) that the sample group adhere to significantly affect their zakat payment behaviour, the clear directions of zakat payment cannot be determined since the criteria for zakat payment for each school of thought are different, complicated and detailed.

Another important finding relates to the trust of zakat payers in the people or institutions that collect zakat and distribute it to the eight target groups. Although the findings from the previous part of this analysis did not show that trust in the people or organisations who distribute zakat would reduce the probability of not fully paying zakat, those who do fully pay zakat and also have trust would be encouraged to significantly increase their zakat payment by $0.297 \%$.

\section{CONCLUSION AND RECOMMENDATION}

This study has identified the demographic and socioeconomic factors that influence the zakat payment behaviour of Thai Muslims, including age, place of residence, family size and the amount of wealth as measured by income and net assets. However, religious factors based on individuals' faith or religious austerity 
are found to have no coherent impact on zakat payment. These findings together indicate that the sample group had 'hard' rather than 'soft' attitudes towards zakat payment. In other words, zakat payment is seen as compulsory charity and an obligation that Muslims have to discharge according to religious principles.

In light of this view, zakat payment is similar in nature to paying taxes in that it involves payment based on Islamic prescriptions without any legal effect. Good Muslims assume primary responsibility for fully paying zakat, specifically at a rate of no less than $2.5 \%$ of the wealth accumulated in the zakat year. This does not include payments made as donations or to charity, which can also be achieved in other forms. Therefore, it is reasonable to believe that attempts to enforce compulsory zakat payment among Thai Muslims, predominantly through moral factors like faith, generosity and helpfulness, may not be fully effective.

Given that better understanding of the assets and liabilities that are subjected to zakat payment is associated with negative payment behaviour, which is contradictory to the positive impact of a higher level of religious education, it is necessary to provide specific guidelines for Thai Muslims on the specific types of wealth that are zakatable or to develop practical tools to assist them in assessing their wealth, together with in-depth knowledge of the importance and necessity of zakat from the religious perspective.

Interestingly, it is found that institutional factors like the trustworthiness of the organisations or individuals who are responsible for managing zakat and higher frequency of zakat payment tend to encourage those who already fully pay zakat to contribute even more. Therefore, official organisations responsible for collecting and distributing zakat should be established at the community, provincial, regional and national levels. Zakat funds that are managed with integrity, transparency and good governance should be exemplified so that people will be encouraged to pay more zakat and the lives of those in need can be lifted correspondingly.

\section{REFERENCES}

Abu Bakar, N. B., \& Abdul Rahman, A. R. (2007). A Comparative Study of Zakah and Modern Taxation. J.KAU: Islamic Econ, 20(1), 25-40.

Al Qaradawi, Y. (1999). Fiqh al zakah (Volume 1): A Comparative Study of Zakah, Regulations and Philosophy in the light of Quran and Sunnah (134ed.), 13(3). Saudi Arabia: King Abdul Aziz University, 110-134.

Alfitri (2005). The Law of Zakat Management and Non-Governmental Zakat Collectors in Indonesia. The International Journal of Not-for-Profit Law, 8(2), November 2005.

Amin, I. M. (2003). Business Zakah Poised for take-off. Akauntan National, January/February, 18-20.

Centre for Development Policy Studies (2007) . Draft Bill on Zakat Foundation Promotion. Academic Paper No.7. Bangkok: Centre for Development Policy Studies, Faculty of Economics, Chulalongkorn University. (in Thai)

Firdaus, M., Beik, I. S., Irawan, T., \& Juanda, B. (2012). Economic Estimation and Determinations of Zakat Potential in Indonesia. IRTI Working Paper Series, WP\#1433-07. 
Hasalem, C. et al. (2007). Report on Zakat Foundation. Academic Paper No.8. Bangkok: Health Promotion Plan for Thai Muslims. (in Thai)

Kamil, M. I. (2005). The Role of Intrinsic Motivational Factors on Compliance behaviour of Zakat on Employment Income. In Zakah Contemporary issue in Malaysia. (1st ed.). Melaka: UiTM. 137-170.

Lunn, J., Klay, R., \& Douglass, A. (2011). Relationship among Giving, Church attendance, and Religious belief: The case of the Presbyterian Church (USA). Journal for the Scientific Study of Religion, 40(4), 765-775.

Muda, M., Marzuki, A., \& Shaharuddin, A. (2006). Factors Influencing Individual Participation in Zakah Contribution: Exploratory Investigation. Paper submitted for presentation at the Seminar for Islamic Banking and Finance 2006, August, Kuala Lumpur.

National Reform Council (2014). Report on Reforming Zakat Foundation Promotion to Reduce Poverty and Draft Bill on Zakat Foundation Promotion. Bangkok: Islamic Social Welfare Reform Board.

National Statistical Office of Thailand (2010). The 2010 Population and Housing Census. Retrieved May 31, 2019, from http://www.nso.go.th/sites/2014/Pages/ pop/table-stat.aspx.

Nik Hassan, N. M. (1991). Zakah in Malaysia: Present and future status. In A. H. Sadeq, A. H. Pramanik, \& N. H. Hassan (Eds.), Development and Finance in Islam (pp. 213-238). Malaysia: International Islamic University Press.

Numsuk, A., Hasalem, C., \& Mmadnor, T. (2012). Success of Zakat and Social Welfare Foundation in Thailand. Bangkok: Health Promotion Plan for Thai Muslims and Thai Health Promotion Foundation. (in Thai)

Reinstein, D. (2006). Does One Contribution come at the Expense of another? Empirical Evidence on Substitution between Charitable Donations. Economics Discussion Papers 2938, University of Essex, Department of Economics.

Sarntisart, I., Saranyapong, S., \& Niyomsuk, O. (2008). Knowledge on Muslim studies in Thailand 1975-2007. Bangkok: Muslim Studies Center, Chulalongkorn University. Supported by National Research Council of Thailand. (in Thai)

Suwanhirunkul, P. (2014). Zakat and Its Effect on Muslim Education Expenditure in Bangkok Metropolis Region. Bangkok: Chulalongkorn University.

Suwanhirunkul, S. (2013). The Potential Impact of Islamic Compulsory Charity Zakat on Alleviating Poverty in Thailand. Bangkok: Chulalongkorn University. 
This page is intentionally left blank 